\title{
19: 40511953-40530104
}

National Cancer Institute

\section{Source}

National Cancer Institute. 19: 40511953-40530104. NCI Thesaurus. Code C41898.

Physical location of CD22_Gene 